\title{
Specificity of designing a House of God in the light of the Orthodox theology
}

\author{
Adam Musiuk \\ Politechnika Białostocka, Wydział Architektury, Pracownia Technicznego Wspomagania Projektowania \\ Polska \\ adam.musiuk@wp.pl
}

Adam Musiuk, Specyfika projektowania Domu Bożego w świetle teologii prawosławnej, Elpis, 18 2016: 87-91.

\begin{abstract}
A house of God is a particular house. According to the Orthodox liturgics the whole world participates in a service - the priest, the faithful gathered, but equally the temple build of a material. It forces the designer to familiarize himself thoroughly with the technical requirements concerning the temple and observe them absolutely, so that the designed home could become the house of God.

Streszczenie: Dom Boży, to dom szczególny. Zgodnie z liturgiką prawosławną w nabożeństwie bierze udział cały kosmos, a więc i kapłan, i lud zgromadzony, ale i materialnie zbudowana świątynia. Zmusza to projektanta do ścisłego zapoznania się z wymaganiami teologicznymi dotyczącymi świątyni i bezwzględnego ich przestrzegania, tak aby zaprojektowany dom mógł stać się Domem Bożym.
\end{abstract}

Keywords: Orthodox church, house, designing

Słowa kluczowe: świątynia prawosławna, dom, projektowanie

\section{Introduction}

Designing a house is a seemingly trivial task. Most people associate a house, in the simplest way of thinking, with building materials and the residents. Still, if one takes a closer look at the task of designing, "building materials" "change" from a general concept into wood, stone, concrete or brick, with particular, individual features of each of the materials mentioned. Also, the "residents" might vary. In most cases it's a family, however, apart from the usual houses we have equally orphanages, old people's homes as well as a community centres or printing houses. Moreover, if we add to that the functional and aesthetic needs, one can see that in many cases the task of designing becomes more and more difficult.

We must explain, however, why in the article we don't describe the discussed building as a church but as a house of God. Originally, Christian services were celebrated in catacombs or in dwelling houses, with time gradually more and more adjusted to the needs of celebration of the divine liturgy. Only in the IV century first churches appeared, but even then they were still called "the house of God". The fact that churches as a distinct type of buildings appeared didn't erase the earlier tradition of celebrating the services in the houses adjusted for that purpose. To this day, particularly in small communities or newly established parishes, an adapted part or an entire house is used as a temple. Therefore, the terms "church" (as a building) and "house of God" can be applied interchangeably. Moreover, in this article we would like to underline, that in a correctly designed temple God lives, therefore it is a house of God. It is particularly evident in the Orthodox Tradition, where the symbolism is particularly strongly emphasized. Let's therefore examine the conditions to fulfil whilst designing a church (in Polish $(\text { cerkiew })^{1}$, in other words a Lord's house ${ }^{2}-$ the house of God.

\section{The difference between the perception of the religious art by the Western and Eastern Churches}

First, we will draw your attention to the different perceptions of the art in Western and Eastern Churches. It is possible that, as one lives in the context of western culture, the lack of such a differentiation may cause many difficulties, which a designer might face during the process of designing. One has to take into consideration that, from the XIII century onwards, there is a clear split in the expression of the religious art of the West and of the East. Until then, despite the fact that the western theology had quite an indifferent attitude towards the art, the sacred art didn't follow in its development the evolution of the western the-

\footnotetext{
Originally, in the old Polish, the word cerkiew (meaning: church) designed equally an orthodox, roman catholic or protestant temple. An identical meaning had the term kościót, designing all the above mentioned temples. It was only at the end of the XVI century that they began to differentiate between the terms kościót and cerkiew, where the latter started being related to the orthodox temple. Cf. Karpluk M., Stownictwo cerkiewne w polszczyźnie XVI w. [in:] Chrześcijański wschód a kultura polska, ed. Łużny R., Wyd. Katolickiego Uniwersytetu Lubelskiego, Lublin 1989, p.129-131

The word cerkiew comes from Greek and means "the Lord's house"
} 
ological thought. Only the introduction of, among others, the perspective, of the play of chiaroscuro and of the optical illusion decidedly shifted the centre of gravity from transcendence of the art to its immanence. Breaking with the canons of the Tradition led to the loss of the spiritual element. Saints, dressed in clothes of the period, looked exactly like everyone around. Studying art more often consisted in carrying out an anatomical study, looking for a beautiful landscape rather than - as it was the case earlier - in referring to the spiritual values. A theologian of the Eastern Church - Paul Evdokimov ${ }^{3}$, discerning the phenomenon recapitulates it as follows: "The (western) art forgot the sacred language of symbols and presence, and started to treat the religious themes in an artistic way. The breath of the Transcendent ceased to permeate it"4. A theologian of the Western Church states: "The whole argument concerning the sacral art, widespread in the West nowadays, concerns the area that reveals a complete distinctiveness of the two sacral types of art of the East and the West. To be exact, the argument reveals first of all, that the religious art in the West, regardless the opinions on the subject, has nothing holy in it in a sense the holy icons are. (...) Everything is an excellent illustration of the fact that the religious art in the West does not belong to the liturgy and no one even imagines that it ever could. (...) More or less since Gothic in our most remarkable, but also in quite usual temples, in which a Holy Mass is celebrated every day, we find everything necessary for awakening or weakening the personal piety, still, nothing distinguishes these interiors from art galleries or museums, no picture or sculpture leads to the union of the faithful present in the church in the common mystery"s.

In the East the things are perceived in an Utterly different way. Here the divine liturgy is celebrated by the priests with the participation of the faithful in a material temple, but at the same time it is an image of the divine liturgy celebrated by Christ and the angels at the heavenly altar. The sacral art of the Orthodox Church tries to include everything in the scope of the liturgical mystery, so that outside the time of the services everything in the church is a waiting for the holy mystery. The sacral art has an appointed, precisely determined status. It is not only a complement of the theology, but a theology existing in a parallel way, as if complementarily. Such a perception puts a strong emphasis on the material image of the house of God: the space of temple, the words, the liturgical gestures, the priest's vestments have a second, deeper symbolic sense. The aesthetical values of the art are subordinated to the needs of the divine liturgy. We find an indication of the key role of the temple and of its vital meaning in the context of celebrating in the divine lit-

Evdokimov Paul (1901-1970) - a layman, professor of St Sergius' Orthodox Theological Institute in Paris; considered to be an heir of the orthodox theological tradition, of which fathers Paul Florensky and Sergius Bulgakov were the representatives; the author of many books on moral and anthropological subjects, such as The Orthodoxy - a fundamental work for the orthodox world of the XX century, containing a synthesis of the orthodox doctrine.

4 Evdokimov P., Życie duchowe w mieście, W drodze, Poznań 2011, p. 184.

Bouyer L., Les catholiques occidentaux et la liturgie byzantine, [in:] Dieu Vivant, vol. 21, Paris 1952, p. 17-31. urgy in the work of blessed Simeon of Thessalonica. In his mystical treatise ${ }^{6}$ he declares: "First, therefore, we tell about the house of God. Since the instrument of the holy liturgy is the temple and the priest, the latter as celebrating it, the first as containing the altar, it's appropriate to talk about both"7. Further, he continues: "The temple then, though made of matter, has a supernatural grace; it was consecrated by an archbishop in mysterious prayers and sprinkled with the holy myrra; and the whole building becomes the dwelling place of God"s.

\section{Transformation of the lay into the sacred}

At what point we can call a building a house? After the foundations have been made? perhaps the walls? or the roof? Perhaps the term "house" can be applied only since the moment, when household members live in it, or otherwise from the moment when appropriate institutions approve it? We don't have here a clear and lucid answer. However, when it's the case of the house of God, the situation is evident. The defining moment is the rite of consecration, when the building is separated from the lay space. The act that makes something sacred, separates it from its empirical conditions, which changes its nature. As a matter of fact, the place is holy by the virtue of presence of God in the same way that holy was the part of the temple containing the Ark of Alliance. During the rite of consecration the bishop, making the sign of cross with the relics proclaims: "The Lord of Hosts, He is the King of glory". When the bishop enters, God takes the place into His possession, changes it into the house of God, whereas the liturgy can be qualified as "divine". The temple as a whole becomes a vivid figure of divine heaven on earth ${ }^{10}$.

\section{Temple as the house of God}

Becoming heaven on earth, the temple in many patristic works is called a house of God. We find multiple comparisons in the writings of blessed Symeon of Thessalonica:

Amongst byzantine mystical treatises, those that explain Christian rituals and symbols, a particularly important place is occupied by the commentary of blessed Symeon of Thessalonica The Temple of God (O światyni Bożej). It is important that the explanations concern the final stage of development of the pontifical liturgy that is the first half of the XV century. In other words, the moment since which, until this day, nothing has basically changed in the orthodox services. It means that the comments of blessed Symeon are valid even now. In addition to that, his mystical treatises prove to have an enormous influence on the whole post-byzantine world. They were printed many times in Greek, modern Greek, Latin and Slavonic languages becoming a model of manuals of the liturgics of the Eastern Church as well as a basis of many dissertations.

Symeon z Tessaloniki, O świątyni Bożej, ed. Minczew G., trans. Maciejewska A., Wyd. Uniwersytetu Jagiellońskiego, Kraków 2007, p. 38.

8 Ibidem.

9 Położenie kamienia wegielnego i poświęcenie cerkwi, Prawosławna Diecezja Lubelsko - Chełmska, Lublin 2006, p. 95.

10 Evdokimov P., Prawosławie, PAX, Warszawa 2003, p. 228. 
"Therefore a church is a house of God despite the fact that it is constructed of non-spiritual matter..."11, or elsewhere: "...so we don't call it any more simply a house, but a holy house (of God)..."12, or: "...a church is dedicated to God and it is His house, and He dwells in it..."13. Saint Dmitry, metropolitan of Rostov, discussing the question of building a church, talks of it as of "building a house of God"14, whereas in the writings of St Herman we read: "A church is the temple of God, it is a particular place of God, a holy place and a house of prayer..."15. More recently P. Evdokimov adds: “...the entire church is holy, because God dwells in it and makes it the house of God..."16. More importantly though, Christ Himself says: "My house shall be called of all nations the house of prayer" (Mk 11, 17) ${ }^{17}$.

\section{Requirements we must fulfil while designing a house of God}

Crossing the threshold of a temple one should immediately and entirely find himself in an utterly different world. It is expressly stated in the liturgical hymn called Cherubic Hymn: "Let's put aside all the earthly worries"18 - indicating the fact that a superior arrangement of the temple does not allow to introduce into it a worldly element. Paul Evdokimov notices: "The sacred sphere penetrates inside, penetrates now and remains, pushing aside the lay time and the lay space. Thanks to the liturgical moments of which the beginning is clearly stated by the expression: «Blessed is the Kingdom of the Father and of the Son and of the Holy Spirit» ${ }^{19}$ we truly find ourselves in the dimension of the Kingdom of God, it comes and it is here, it opens itself under the influence of the symbolic action and symbolic acts" $^{\prime 20}$.

One should therefore assume such fittings of the house of God so that the designed things would not become the furniture only, but so that they would be an element of the temple in the theological context. The temple is an organized space - this is what distinguishes it from the surroundings. However, this arrangement, from the point of view of a faithful, is supposed to direct him towards theophany. The point is that during the divine liturgy one should find

\footnotetext{
11 Сочинения блаженного Симеона, архиепископа Фессалоникийского [in:] Писания Святых Оти,ов и учителей Церкви, относящиеся к истолкованию православного богослужения, ТКиК, Санкт-Петербург 1859, vol. 2, p. 179.

12 Ibidem, p. 180.

13 Ibidem.

14 Дьяченко Г., Практическая Симфония для проповедников Слова Божия, Свято-Троицкая Сергиева Лавра, Сергиев Посад 1992, p. 495.

15 Quotation from: Nowe tablice czyli o cerkwi, liturgii, nabożeństwach $i$ utensyliach cerkiewnych. Objaśnienia Beniamina arcybiskupa Niżnego Nowogrodu i Arzamasu, ed. Minczew G., trans. Petrov I., Wyd. Uniwersytetu Jagiellońskiego, Kraków 2007, p. 7.

16 Evdokimov P., Prawosławie..., p. 216.

17 Quotation from the internet King James' version of the Bible.

18 Święta Liturgia św. Jana Złotoustego, ed. Pietkiewicz P., Orthdruk, Białystok 2008, p. 63.

19 Ibidem, p. 33.

20 Evdokimov P., Życie duchowe..., p. 172.
}

oneself in the presence of God, in His light and in order to adore Him.

The divine liturgy initiates into the sacral language, introduces into the world of symbols. Symbol by its nature is subordinated and participates in the thing that it symbolizes - the symbolized thing is present in its symbol. Symbolism of the temple as a house of God in architecture is realized basically in the sanctuary and it's created by: the symbolism of the exterior form of the temple as sacrum, symbolism of the sanctuary and its iconography, symbolism of the form of the altar and ciborium, symbolism of the altar apse, archetypes of orientation and concentration as well as ecstatic archetypes ${ }^{21}$.

\section{Arrangement of the temple}

The above outlined analysis indicates a complete dependence of the sacral art on the service. There is no possibility of existence of the art functioning inside the house of God without its being included in the divine liturgy. It is valid equally for such obvious elements as icons, liturgical utensils, priest's vestments as it does for each of, even least important, detail. For example, P. Evdokimov, discussing the iconographical program, precisely speaks of the appearance of the figures: "The elongated and slender figures of the icons and frescoes illustrate the heading upwards"22. That remark seems already very detailed, still Paul Florensky ${ }^{23}$ notices one even smaller detail - the necessity of filling the temple with the smoke of the incense. "The church architecture, for example, takes into consideration, apparently insignificant, question of permeating of the smoke of the incense inside the temple. I mean the trailing of blue strips of smoke up over the frescoes or their spiralling around the columns supporting the dome. The movement of those spiralling up of strips of smoke, permeating each other, causes the architectural space of the temple to widen almost infinitely. In the thick strips of smoke the dome fades away, the sharp edges and hard surfaces become smoother, everything as if disperses itself in the continuous movement of smoke, at the same time as if gaining life"24.

The great number of details and widely extended requirements seem complicated and difficult to understand. However this understanding is inevitable for the comprehensive fathoming out of the divine liturgy, and in consequence the appropriate designing of the house of God. As

21 Uścinowicz J., Symbol. Archetyp. Struktura. Hermeneutyka tradycji $w$ architekturze świątyni ortodoksyjnej, DWiP Politechniki Białostockiej, Białystok 1997, p. 127.

22 Evdokimov P., Prawosławie..., p. 230.

23 Florensky Paul (1882-1937) - a priest as well as an outstanding scientist: mathematician, physicist, philosopher, theologian, poet. In 1915 he was nominated the professor of philosophy, in 1924 he received the title of the full professor of physics. The author of, published in 1914, The Pillar and Support of the Truth, a book considered to be the beginning of a new era in the Russian theology. He spent the last years of his life in Soviet forced-labour camps, and was shot in 1937.

24 Florenski P., Ikonostas i inne szkice, Bractwo Młodzieży Prawosławnej w Polsce, Białystok 1997, p. 43. 
pertinently notices archbishop Benjamin ${ }^{25}$ : "The services of our Orthodox Church, even with one only glance at their beauty, evoke in the humble souls admiration; but an incomparably greater admiration equally in the clergy as in the faithful gathered and praying can be prompted by the understanding of mysterious power and essence of celebrating the church services"26.

We can see therefore the necessity of exhaustive, literal, but also symbolical explanation of the service. Such a need was already recognised in the first ages of Christianity and we have multiple texts concerning that matter. For the byzantine-slav world four texts have the greatest importance: St Maximus the Confessor's (c. 580-662) Mystagogica ${ }^{27}$, St Herman's (c. 634-733) Historia Ecclesiastica ${ }^{28}$, Nicholas Kabasilas' (c. 1320-1391) Sacrae liturgiae interpretatio ${ }^{29}$, as well as De sacra liturgia ${ }^{30}$ and Expositio de divino templo ${ }^{31}$ (Polish translation: O światyni Bożej32) of blessed Symeon of Tessalonika (c. 1381-1429).

It appears, therefore, that a person who wants to understand the essence of the Eastern rite must consider those texts a required reading. However, the byzantine mystagogies and their Slav replicas in most cases haven't been so far translated into Polish or English, which may create a certain difficulty. Unfortunately, those texts - scattered in old prints and specialist scientific editions - are sometimes difficult to access, even for those who specialise in liturgics or art history. We can freely access the mystagogical treatises only in Greek and Latin or in Russian translations.

\section{Mystagogical treatise of Symeon of Thessalonika}

Let's have a closer look at the liturgical commentary of blessed Symeon - The Temple of God, considered by many theologians as one of the most important mystagogical treatises. The text is a catechetical interpretation of most important for the Holy Eucharist symbols, connected with sacred space, liturgical gestures of a bishop, priest and deacon, with holy utensils and liturgical vestments.

Consisting of 103 paragraphs treatise, basically, in paragraphs $2-48^{33}$ discusses the problems we are interested in.

\footnotetext{
25 Archbishop of Nizhny Novgorod Benjamin (Krasnopevkov; 1739-1811) - hierarch, orthodox theologian. In 1803 he published his most significant work NewTables (Nowe tablice...). This treatise - a compilation of the mystagogical works of the Church Fathers - is a thorough commentary and explanation of the meaning of individual elements of equipment of the orthodox churches and the ordo of the services in the last period of its development (since the times of archbishop Benjamin until now the divine liturgy remains unchanged). The treatise is quite popular even in our times - it has been printed more than twenty times until now, most recently in 2007.

26 Nowe tablice..., p. XIII.

27 PG 91, 657-718.

28 PG 98, 381-453.

$29 \quad P G 150,368-492$.

$30 \quad P G 155,253-304$ (for the purpose of this article we used the Russian translation of the work: Сочинения блаженного Симеона...).

31 PG 155, 697-750.

32 Symeon z Tessaloniki, O świątyni Bożej..., p. 33-93.

33 Ibidem.
}

In paragraph 2 we find information concerning the temple and the altar. Paragraph 3 is entirely dedicated to the temple. In the following, the fourth paragraph, we learn about individual elements of the temple: the narthex, the nave, and the sanctuary. Paragraphs 5, 10,13,14, 15, and 17 concern the Holy Table ${ }^{34}$. Paragraph 6 deals with the veil of the temple, in the seventh we read about the balustrade. In the next two paragraphs -8 and 9 - we learn about the cover of the Holy Table: katasarkos. Additionally paragraph 9 describes trapezophorion ${ }^{35}$. Paragraph 11 concerns the steps of the altar. In paragraph 13 we read about the Gospel Book and about the cross, in paragraph 14 we learn about the relics of the holy martyrs. In paragraph 16 we learn about the cloths covering the Holy Table. In the 19th paragraph we read about the incense, and in the 20th about the light. Paragraph 21 explains, what mean the parts of the temple outside the sanctuary. In the following, 22nd we find a dissertation about the veils at the entrance to the narthex. Paragraph 23 concerns the ambone. In paragraph 24 we learn about the decoration of the temple. Paragraphs 33 to 45 and 47 inform us about the vestments. In paragraph 46 we learn about the High Place ${ }^{36}$. The last paragraph of the basic part concerning the temple, the 48th informs us of the Royal Door. In the next paragraphs we find mentions concerning: the altar (paragraphs 54, 56, 57, 60, 72, 99), candles (paragraph 54), the Gospel Book (paragraphs 55, $61,66,67$ ), the Royal Doors (paragraphs 57, 83), the Holy Table (paragraphs 58, 80, 85, 86, 90), two-branched candlestick $^{37}$ (paragraph 59), three-branched candlestick ${ }^{38}$ (paragraphs $61,62,70,71,82$ ), the High Place (paragraph 63), the Apostle Book ${ }^{39}$ (paragraph 64), incensing (paragraphs 68,100 ), the vestments (paragraphs $69,70,78,90$ ), the liturgical utensils (paragraphs 76, 79, 86, 92, 93, 94, 99, 100, 101,103 ), the Prothesis ${ }^{40}$ (paragraphs 78,100 ) and the nave (paragraph 82).

In the descriptions above we don't find directly mentioned measurements or forms of the described elements because it was not the aim of the mystagogies as they aren't the textbooks for architects. However we find here the indications we cannot ignore while designing a church. Moreover, we should enrich our knowledge by reading the subsequent works, since writing the mystagogical treatises as well as other books discussing and explaining the divine liturgy in the Eastern Tradition consisted in compiling the works written earlier and adding to that the author's own comments. Therefore, familiarizing oneself with the works

\footnotetext{
34 Holy Table/Altar (cs. prestot Church Slavonic is used as the liturgical language in the Orthodox Church in Poland) - the most sacred element of the church, placed in the central part of the sanctuary. It symbolizes at the same time Lord's Throne and Lord's Tomb.

35 Trapezophorion - richly decorated cloth covering the Holy Table.

36 The High Place - higher place in the sanctuary placed East of the Holy Table intended for a bishop.

37 Two-branched candlestick (dikerion) - symbolizes two natures of Christ.

38 Three-branched candlestick (trikerion) - symbolizes the Holy Trinity. 39 The Apostle Book - a liturgical book containing the Acts of Apostles and the Epistles.

40 The Prothesis (cs. zertwiennik) - the table of oblation placed in the northern part of the sanctuary.
} 
written after The Temple of God was printed, we can be sure that we will find in them also all the contents written down by blessed Symeon. In the later works they will be just broadened or additionally commented. Particularly worth recommending is the - mentioned earlier - commentary of archbishop Benjamin The New Tables ${ }^{41}$.

\section{Conclusion}

The house of God is a particular house. In the light of statements of the orthodox theologians, it is a real image of God and at the same time an image of the whole world, of which the material dimension can be perceived by one's mind, but which is full of invisible disembodied forces. The

41 Nowe tablice... designer is expected not only to prove his good knowledge of his trade, a sense of form, but also the right theological preparation. Only at the moment of consecration by a hierarch, after declaration that all the theological requirements were fulfilled, it changes form an ordinary house into the house of God, the house which in its entirety becomes a vivid figure of the divine heaven on earth. It should be particularly emphasized here the word "comprehensive" as according to the orthodox liturgics in the divine liturgy the whole cosmos participates, therefore and the priest, and the people gathered, but equally the materially constructed temple. It forces the designer to thoroughly acquaint himself with the theological requirements concerning the temple and adhere to them absolutely so that the designed house could become the house of God.

The article was written as a part of research work $S / W A / 2 / 2016$

\section{Bibliography}

Bouyer L., Les catholiques occidentaux et la liturgie byzantine, [in:] Dieu Vivant, vol. 21, Paris 1952

Дьяченко Г., Практическая Симфония для проповедников Слова Божия, Свято-Троицкая Сергиева Лавра, Сергиев Посад 1992

Evdokimov P., Prawosławie, PAX, Warszawa 2003

Evdokimov P., Życie duchowe w mieście, W drodze, Poznań 2011

Florenski P., Ikonostas i inne szkice, Bractwo Młodzieży Prawosławnej w Polsce, Białystok 1997

Karpluk M., Słownictwo cerkiewne w polszczyźnie XVI w. [in:] Chrześcijański wschód a kultura polska, ed. Łużny R., Wyd. Katolickiego Uniwersytetu Lubelskiego, Lublin 1989

Nowe tablice czyli o cerkwi, liturgii, nabożenstwach i utensyliach cerkiewnych. Objaśnienia Beniamina arcybiskupa Niżnego Nowogrodu i Arzamasu, ed. Minczew G., trans. Petrov I., Wyd. Uniwersytetu Jagiellońskiego, Kraków 2007
Patrologia Graeca, ed. Migne J.P., Paris 1865-6, vol. 91, 98, 150, 155.

Położenie kamienia węgielnego i poświęcenie cerkwi, Prawosławna Diecezja Lubelsko - Chełmska, Lublin 2006

Сочинения блаженного Симеона, архиепископа Фессалоникийского [in:] Писания Святых Отиов и учителей Церкви, относящиеся к истолкованию правоставного богослужения, ТКиК, Санкт-Петербург 1859, vol. 2

Symeon z Tessaloniki, O świątyni Bożej, ed. Minczew G., trans. Maciejewska A., Wyd. Uniwersytetu Jagiellońskiego, Kraków 2007

Święta Liturgia św. Jana Złotoustego, ed. Pietkiewicz P., Orthdruk, Białystok 2008

Uścinowicz J., Symbol. Archetyp. Struktura. Hermeneutyka tradycji $w$ architekturze świątyni ortodoksyjnej, DWiP Politechniki Białostockiej, Białystok 1997 